PC-069 自己呈示の内在化は自己欺瞞の産物 か一自己欺瞞特性と自己呈示効力感 に着目して一

○上田 泉介 ${ }^{1}$, 清河 幸子 $^{1}$

(名古屋大学)

キーワード : 自己呈示の内在化, 自己欺眐, 自己呈示効力感

自己呈示した方向に自身の認知や行動が変化する現象を自己呈示の内 在化という。本研究では, この現象が自身の目標追求に合致した情報を 優先させる情報処理の偏りである自己欺睓の結果として生じるという仮 説を検討した。具体的には，(1)自己欺瞞特性が高いほど自己呈示の内在 化が強く生じる，(2) (1)の関連は自己呈示効力感に媒介されるという 2 つの仮説を検討した。39名の参加者が，自身の外向性抢よび自己欺瞞特 性に関する尺度（BIDR-J）に回答した 1 週間後に実験に参加し，外向的 もしくは内向的に自己紹介をするよう求められた（順に，外向条件，内 向条件と呼ぶ)。その後, 再び自身の外向性と自己呈示効力感に関する尺 度に回答した。事前に測定された外向性から予測される外向性の值と自 己紹介後に測定された外向性の值のずれを自己呈示の内在化の程度の指 標として使用した。その結果, 両条件において, 自己欺眸特性と外向性 の認知の変化に有意な関連は見られず，仮説（1）は支持されなかった。し かし, 外向条件では, 自己呈示効力感の有意な媒介効果が見られ, 仮説 (2)が支持された。一方，内向条件では自己呈示効力感の有意な媒介効果 が見られず仮説 (2) は支持されなかった。

\section{PC-070＼cjkstart生活困窮状態にある単身男性高齢者 における被援助志向性の特徵}

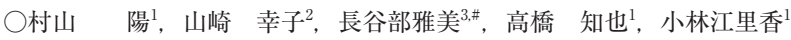
( ${ }^{1}$ 東京都健康長寿医療センター研究所, ${ }^{2}$ 文京学院大学, ${ }^{3}$ 聖学院大学) キーワード：単身男性高齢者, 生活困窮, 被援助志向性

生活困窮状態にある単身男性高齢者は，他者に援助を求めることに消 極的であることが示されている一方で, 援助を求めることをどのように 認識しているのか検討されていない。そこで, 生活困竆に陥った単身男 性高齢者の被援助志向の特徴を明らかにする。方法 : 都内の養護老人ホー ム A に措置入所した男性高齢者の内, 入所前に単身であった 29 名（生活 困窮経験者）に対し半構造化面接を行った（79.7 55 .9歳）。面接内容は, 他者から助けてもらうことについての考光等を尋ねた。 KJ 法を参考に発 言内容が似たもの同士をグループ化してカテゴリー名を付与するボトム アップ型の分類を行った。結果 : 被援助志向は 5 タイプ (1)自立型： $\mathrm{n}=$ 12, (2)諦め型 : $n=8$, (3)互助型 $: n=3$, (4)希求型 $: n=2$, (5)他者志向 型： $n=2$ ) に分類された。(1)自立型と(2)諦め型には，援助要請に否定的 な態度が認められた。(1)自立型は自力で解決したいという男性性役割意 識, (2)諦め型は過去の援助要請の失敗体験が，それぞれ援助要請の抑制 につながっていた。一方で(3)互助型，(4)希求型，(5)他者志向型は周囲と の互助を経験しており, 援助要請にも肯定的な態度がみられた。ただし， 社会的孤立状態のためサポート源がそしく援助要請に至らなかったこと が示された。

\section{PC-071ライフキャリア意識と人生の意味 感，意味の源との関係の検討}

\author{
○李 佳奇 ${ }^{1}$ \\ (1関西大学) \\ キーワード : ライフキャリア意識, 人生の意味感, 意味の源
}

ライフキャリア意識と意味の源，人生の意味感についての関係を詳しい 検討するため, インターネットで，関西地方にある私立 4 年制大学に在 籍している学生334名（男性153名, 女性181名）に, (1) Meaning in Life Questionnaire（MLQ）(島井・大竹，2005）の日本語版10項目 7 件法, (2)ライフキャリアの能力・態度に関する尺度（河崎，2010）21項目 5 件 法, (3) Sources of Meaning Profile-Revised (SOMP-R) (Scheffold, et al. 2014） 17項目 7 件法を実施した。重回帰分析の結果，ライフキャリア意 識は意味の源, 人生の意味感の両方に影響されることが分かった。そし て, 共分散構造分析の結果, ライフキャリア意識は意味の源, 人生の意 味感の両方に影響されるものの，意味の源は直接な要因ではなく，人生の 意味感を通じ，ライフキャリア意識に影響する（GFI=.983; $\mathrm{AGFI}=.952$ $\mathrm{CFI}=.986 ; \mathrm{REMSA}=.053 ; \mathrm{AIC}=55.324)$ 。意味の源を重視すれば，大学 生の人生の意味感が向上でき，ライフキャリア意識も高める。このプロ セスはキャリアカウンセリングに運用できれば，大学生の就職活動の支 援を役に立ち, 就職不安を低減できると予想される。

\section{PC-072 行動再解釈による潜在態度および顕 在態度の变容}

藤島 喜嗣1, 外赤友美恵1,*, 花田紗織里 ${ }^{1, \#}$

(昭和女子大学)

キーワード : 再解釈, 態度, 感情誤帰属手続き

再解釈とは, 行動記述から導かれた解釈で，後続情報により既存意味 が消失し，新しい意味に置き換わることを指す。Mann \& Ferguson (2015, 研究 1 a) は, 最初に人物の否定的行動記述を見せ, 感情誤帰属手 続き（AMP: Payne, et al., 2005）を用いて態度測定した。その後, 付加 情報を提示して再解釈操作を行い，再びAMP と質問紙で態度測定した。 その結果, 再解釈を促した場合, AMP, 質問紙いずれにおいても評価が 好転した。本研究は, 研究 1 として, この研究 1 a の直接的追試を実施 した。その結果，質問紙では再解积効果が見られたが，AMPでは見られ なかった。この理由としてネガティビティバイアスの関与が考えられた。 そこで研究 2 では, 手続きを変更し, 肯定的な印象が後続の否定的な追 加情報によって覆るかを検討した。その結果, 研究 1 と同様, 質問紙で は再解积の効果が見られたが，AMPでは見られなかった。再解釈の過程 とその限界について考察した。 